\author{
Miroslav GLIŠIĆ, Ph.D. ${ }^{1}$ \\ Branislav ĐORĐEVIĆ, Ph.D. ${ }^{2}$ \\ Dejan STOJKOVIĆ, Ph.D. ${ }^{3}$
}

\title{
THE EU GLOBAL STRATEGY \\ - A POSSIBLE FRAMEWORK FOR DEEPENING COOPERATION WITH THE REPUBLIC OF SERBIA IN THE DEFENCE DOMAIN ${ }^{4}$
}

https://doi.org/10.18485/iipe_balkans_rssc.2020.ch18

Abstract: This paper deals with the research question of how the implementation process of A Global Strategy for the European Union's Foreign and Security Policy in the area of security and defence affects a possible deepening of cooperation with the Republic of Serbia in the defence domain. The authors analyse the EU's Implementation Plan on Security and Defence, the Commission's European Defence Action Plan, and the EU-NATO Joint Declarations to identify opportunities for improvement of cooperation between the Republic of Serbia and the European Union. The tested general hypothesis within this research is the following: the EU Global Strategy implementation has a positive impact on defence cooperation with the Republic of Serbia, and also for engagement within the Common Security and Defence Policy, and provides concrete deliverables through several different ways thereby enhancing the integrative capacities for the EU membership. Taking into consideration the above-mentioned, this paper seeks to find out how the implementation of the EU Global Strategy can trigger deeper cooperation with the Republic of Serbia in the area of defence using: (1) actions proposed within the Implementation Plan on Security and Defence such as to set capabilities development priorities, adjust structures, tools

\footnotetext{
${ }^{1}$ Ministry of Defence, Belgrade, Serbia. E-mail: miroslav.glisic@gmail.com

${ }^{2}$ Full Professor, Director of the Institute of International Politics and Economics, Belgrade, Serbia. E-mail: bdjordjevic@diplomacy.bg.ac.rs.

${ }^{3}$ Associate Professor, Defence University, Ministry of Defence, Belgrade, Serbia. E-mail: dej.stojkovic@gmail.com.

${ }^{4}$ The paper presents findings of a study developed as a part of the research project "Serbia and challenges in international relations in 2020", financed by the Ministry of Education, Science, and Technological Development of the Republic of Serbia, and conducted by Institute of International Politics and Economics, Belgrade.
} 
and instruments as well as to take forward partnerships; (2) opportunities provided by the European Defence Action Plan for supporting investments in joint research and the joint development of defence equipment and technologies; and (3) facilities for cooperation with the European Union and NATO in the framework of EU-NATO Joint Declarations in the areas of hybrid threats, operational cooperation, cyber security, defence capabilities, industry and research, exercises and capacity building. Through a detailed analysis and modelling of different circumstances and factors, we can conclude that almost each of the above contents in certain segments provides positive conditions for enhanced cooperation between the Republic of Serbia and the European Union.

Keywords: the European Union, the EU Global Strategy, the EU Security and Defence, the Republic of Serbia, Defence Cooperation, PESCO, CARD, EDF.

\section{INTRODUCTION}

The renewal process of the European Union's Common Security and Defence Policy (CSDP) started in 2013 when significant work was undertaken by the Commission, the High Representative for Foreign Affairs and Security Policy, the European Defence Agency and the Member States. ${ }^{5}$ Following this trend, in December 2013, for the first time since the entry into force of the Lisbon Treaty, the European Council held a thematic debate on defence to identify priority actions for deepening cooperation in the mentioned domain. ${ }^{6}$ It was very important due to the fact that Europe's strategic and geopolitical environment has been evolving rapidly since 2003 when the European Security Strategy - A Secure Europe in a Better World was adopted. Also, on the other side, defence budgets in Europe were constrained and European defence markets were fragmented. Accordingly, the European Council invited the High Representative, in close cooperation with the Commission, to assess the

\footnotetext{
${ }^{5}$ Beginnings of a Common Foreign and Security Policy, including also beginnings of a common defence policy, were introduced by the Treaty of Maastricht on 9 December 1991.

${ }^{6}$ During the meeting on 19/20 December 2013, the European Council has identified a number of priority actions within three areas: (1) increasing the effectiveness, visibilities and impact of the Common Security and Defence Policy; (2) enhancing development of capabilities and (3) strengthening Europe's defence industry. Thus, the European Council is committed to delivering key capabilities in four critical domains: air-to-air refuelling, surveillance drones, satellite communications and cyber defence (European Council, 2013, paragraphs 4 and 11).
} 
impact of changes in the global environment and to submit a report in the course of 2015 (European Council, 2013, paragraph 9). In line with this task, the strategic review titled The European Union in a changing global environment - a more connected, contested and complex world was presented in June 2015. This document called for a new common, comprehensive and consistent EU global strategy, taking into account that the world has become more dangerous, divided and disorienting since the adoption of the European Security Strategy in 2003 (Missiroli, 2015, pp. 123-152). Thus, the High Representative finally received a clear mandate to produce a completely new strategy on foreign and security policy in close cooperation with the Member States and submit this document to the European Council by June 2016 (European Council, 2015, paragraph 10b).

New EU strategy, Shared Vision, Common Action: A Stronger Europe A Global Strategy for the European Union's Foreign and Security Policy was presented in June 2016 by the High Representative. The European Council welcomed the presentation of the Global Strategy and invited the High Representative, the Commission, and the Council to take the work forward to implement in practice this strategic document (European Council, 2016a, paragraph 20). A better world where Europe has never been so prosperous, so secure nor so free, including a period of peace and stability unprecedented in European history (European Security Strategy), has been changed into more complex, more connected and more contested (the EU Global Strategy). Thus, as Dyson and Konstadinides (2013) noticed, the balance of power and balance of threat are becoming more and more important drivers of the EU's Common Security and Defence Policy, which implies that neorealism is also becoming a more tailored theoretical framework to understand EU's security and defence cooperation in comparison with constructivism and institutionalism. In practice, as Biscop pointed out, the EU Global Strategy represents a return to realpolitik in the original sense of the term in order to achieve ideals in a realistic way $(2017$, p. 31$)$.

In accordance with the recommendations given by the European External Action Service, the implementation package of the Global Strategy in area of security and defence consists of three major pillars: (1) new political goals and ambitions for Europeans to take more responsibility for their own security and defence; (2) new financial tools to help the Member States and the European defence industry to develop defence capabilities; and (3) set of concrete actions to improve cooperation between the EU and NATO. Within the mentioned package, concrete 
tools such as the Implementation Plan on Security and Defence, the European Defence Action Plan, and the EU-NATO Joint Declarations provide a solid opportunity for enhancing defence cooperation among the Member States. In addition, the implementation process of the EU Global Strategy can also have a positive impact on deepening cooperation in the defence domain between the European Union and third countries, including the Republic of Serbia. This fact poses at the same time security challenge and a great opportunity for the Republic of Serbia within changing European security and defence structure and the changing of the world as a whole.

\section{IMPLEMENTING THE GLOBAL STRATEGY: DEFENCE AND SECURITY PACKAGE}

\section{Strategic Reflection and Development of the Global Strategy}

The European Security Strategy - A Secure Europe in a Better World, adopted on 12 December 2003, was the first European Union's document which defined security environment, identified security challenges, and the subsequent implication for the European Union. ${ }^{7}$ Five years later, French President Sarkozy raised a proposal 'to equip the European Union with a bolder security strategy that would progressively affirm its position as a first-rank player for peace and security' (European Parliament, 2016a). Hence, the EU Member States agreed to examine the implementation of the European Security Strategy in order to propose a possible way for improvement. The process ended in a very modest way, adopting the Report on the Implementation of the European Security Strategy in December 2008 with the recommendation given by the European Council that the European Union needed to be still more capable, more coherent and more active (European Council, 2008, paragraph 30).

The renewal process of drafting a purely new strategy officially started in 2014 with the assessment of the EU's global environment. During the drafting process of the Global Strategy, many institutes, think-tank organizations and other relevant actors provided a lot of efforts to define

\footnotetext{
${ }^{7}$ European Security Strategy - A Secure Europe in a Better World, in accordance with the statement given by Missiroli, has never truly been a strategy: '... it is still a moot point whether this document was truly a strategy in its own right or a rather general doctrine, a combination between a fresh appraisal of the new security environment and a broad set of policy guidelines and recommendations' (Missiroli, 2015, p. 10).
} 
the European Union's security environment. ${ }^{8}$ The conclusions were almost the same with assessments that the world is becoming more and more complex, and instability is coming from the South and the East. Also, the threats are not purely military, and in the contemporary circumstances encompass cyber and hybrid warfare, piracy, terrorism, migration, jihad extremism, large-scale regional conflicts - especially in the MENA region, the proliferation of weapons of mass destruction and threats to energy and environmental security. ${ }^{9}$ On the other hand, the end of the Cold War and also the financial crisis in 2008, with austerity measures, have had a negative impact on the defence budget and military capabilities in the European Union's Member Countries. Also, the world's economic centre of gravity is moving to Asia. Thus, the United States' pivot to the AsiaPacific region is getting more and more important for state administration in Washington, D.C. In accordance with the Report of CEPS Task Force, all the above-mentioned has eroded the European Union's role as a security actor in a multipolar world and made the Common Security and Defence Policy the weakest link in the European integration project (Centre for European Policy Studies, 2015).

To appraise and address the contemporary EU's global environment, the strategic review named The European Union in a changing global environment - A more connected, contested and complex world was presented by the High Representative during the European Council meeting in June 2015. ${ }^{10}$ Also, as mentioned before, during this meeting, the High

\footnotetext{
${ }^{8}$ One of the most comprehensive is a study issued in 2014 by the European Union Institute for Security Studies within the Chaillot Paper series - A changing global environment. This study explores changes in a global environment through thematic (human, physical, technological and systemic environment) and through geographic (Eastern, Southern, Further South and Further East environment) lenses (Missiroli et al., 2014).

${ }^{9}$ As Keohane emphasizes: 'Until recently, all EU military efforts were focused on international security beyond the EU's borders, and were carried out through the Common Security and Defence Policy framework, housed within the EU's foreign policy structures. This is changing slightly, due to the migrant crisis and the threat from terrorism, which are simultaneously an internal and external security challenge' (Keohane, 2016, p. 31).

${ }^{10}$ The document The European Union in a changing global environment identifies three main features of the global environment: (1) A more connected world, whereby a surge in global connectivity and human mobility challenges traditional approaches to migration, citizenship, development and health, while at the same time facilitating crime, terrorism and trafficking; (2) A more contested world in which fragile states and ungoverned spaces are expanding, as a result of instability and violence triggered by poverty, lawlessness,
} 
Representative was tasked to prepare the EU Global Strategy in close cooperation with the Member States and to submit it to the European Council by June 2016 (European Council, 2015, paragraph 10b).

As recommended by Bakker et al., the new Global Strategy should replace the current European Union's way of 'constructive ambiguity' in developing defence cooperation with a real political commitment (2016, p. 7). It means that almost seventy years after French Prime Minister Pleven proposed his plan to establish the European Defence Community, the European Union and the Member States need to formulate and conduct an effective model for defence cooperation and integration to cope with current security challenges and austerity.

Taking into account the above-mentioned, many scholars have proposed several models of deepening European defence cooperation and integration. Andersson et al. (2016) illustrate five possible futures of European defence from 'Bonsai armies' through 'Defence Clusters' and 'Peace operations' to 'European NATO' and 'European Army' with remarks that any future European arrangement depends on the capabilities, resources, and cooperation. Also, the Centre for European Policy Studies in its report More Union in European Defence proposes a brand new framework - the 'European Defence Union which calls for a unified strategic process, more effective institutions, an array of more integrated armed forces, a common budget and a single and comprehensive defence market' $(2015$, p. 6). Apart from the scholars' point of views, the European Parliament in November 2018 proposed that the European Defence Union should be launched as a matter of urgency, in two stages and based on a system of differentiated integration: (1) activation of the Permanent structured Cooperation and (2) implementation of the EU Global Strategy as a whole. In addition, the European Commission proposed three scenarios which are illustrative in nature and do not prejudge the final legal and political European Union's position: (1) Security and Defence Cooperation - in accordance with this scenario, the European Union's Member States would cooperate on security and defence more frequently than in the past; (2) Shared Security and Defence - within this scenario the Member States would show far greater financial and operational solidarity in the field of defence, building

corruption and conflict-ridden electoral politics: (3) A more complex world where power is shifting towards other regional players in the developing world and is increasingly shared between state and non-state actors (European Parliament, 2016a, pp. 3-4). 
on a broader and deeper understanding of respective threat perceptions and convergence of strategic cultures; and (3) Common Defence and Security - in line with this scenario, the Member States would deepen cooperation and integration towards a common defence and security which means that such a security and defence union would be premised on the global strategic, economic and technological drivers, as well as a political push from European citizens for common European security and defence (European Commission, 2017).

In any case, expert discussions and political talks of the European Union's security and defence have always been like a double-edged sword. It was also the case during the process of drafting the Global Strategy, primarily when we are talking about the EU's level of ambitions and strategic autonomy as one of the key concepts in this document. Due to the fact that the Member States were deeply divided regarding the EU's level of ambitious, strategic autonomy, including also a full spectrum of defence capabilities, all here mentioned concepts were vaguely defined in the Global Strategy. In addition, the ambitious approach of the European Union was also opposed by the United States of America in order to preserve NATO and transatlantic bond. In EU Defence Cooperation: Progress Amid Transatlantic Concerns, Brattberg and Valašek comment that 'terms like strategic autonomy, European army, and sovereignty risk are reinforcing certain U.S. leaders' perception that new EU defense initiatives are being designed to undermine the centrality of NATO in European security' (2019, p. 14). Owing to that, the level of ambition and strategic autonomy were mentioned in the Global Strategy related to the priorities of the EU's external action only as 'important for Europe's ability to promote peace and security within and beyond its border' (European External Action Service, 2016, p. 9).

To promote European shared interests, the Global strategy pursues five priorities: (1) the Security of the European Union; (2) State and Societal Resilience to European East and South; (3) an Integrated Approach to the Conflict; (4) Cooperative Regional Orders and (5) Global Governance for the $21^{\text {st }}$ Century (European External Action Service, 2016, pp. 9-10).

As Biscop noticed: 'The pursuit of the first three priorities especially clearly reflects the modesty or realism imposed by principled pragmatism, by emphasising our own security, the neighbourhood, and hard power, and by no longer emphasising democratisation' (2017, p. 31). 


\section{The Implementation Process of the Global Strategy in the Security and Defence domain}

To translate the Global Strategy into concrete aims, priorities, objectives and procedures, Bakker et al. (2016) mentioned three very important recommendations: (1) peer pressure, assessment and accountability; (2) alternative formats and (3) financial incentives. Also, Giegerich observes the language of the Global Strategy does not allow for the European Union to be niche actor, due to the fact that accepting a niche role would mean accepting that the vision of the European Union as an international actor with global responsibility for peace and security has failed (2016, p. 28).

In order to implement the Global Strategy and move from a shared vision to common action, decisive steps have been taken on security and defence. In line with the mentioned major pillars within the implementation package in the security and defence domain, the European Union has taken three main actions to foster deeper cooperation in the defence domain and adjust structures, procedures, tools, and instruments accordingly. First, the Council of the European Union developed the Implementation Plan on Security and Defence on 14 November 2016 in order to set out the level of ambition and the way forward in the future development of security and defence policy (Council of the European Union, 2016c). Second, the European Commission adopted the European Defence Action Plan on 30 November 2016 to help the Member States to boost research and spend more efficiently on joint defence capabilities, thus fostering a competitive and innovative defence industrial base and contributing to enhancing European citizens' security (European Commission, 2016). Third, the European Union and NATO signed two EU-NATO Joint Declarations on 8 July 2016 and 10 July 2018 to give new momentum and new substance to the Strategic Partnership between these two organizations (European Council, 2016b and 2018). These three actions are complementary and mutually reinforcing. As mentioned in The European Union and CSDP - State of Affairs, the first gives the main direction and charts the way ahead in security and defence, the second helps provide the instruments needed to promote defence-related cooperation, and the third places these efforts in the larger context of EUNATO cooperation (Iklody, 2017, p. 42). Also, this approach is in line with the recommendation given by Bakker et al. that deepening defence cooperation should be based on a system of 'positive' peer pressure, no 'naming and shaming', but 'naming and praising' (2016, p. 8). 
There are several detailed analyses regarding the implementation process of the Global Strategy such as Walking the Strategic Talk - A Progressive EU Foreign Policy Agenda For the Future (Pirozzi and Ntousas, 2019), Security and Defence: A Glass Half Full (Koenig, 2018) and The European Union's Global Strategy - Three Years on, Looking Forward (European External Action Service, 2019). All of these studies pointed out that significant progress has been achieved within the implementation process of the Global Strategy and proved that the Global Strategy is rather a compass for concrete actions than a theoretical concept.

\section{The Implementation Plan on Security and Defence}

The Implementation Plan on Security and Defence was adopted by the Council of the European Union on 14 November 2016 with the aim to set out proposals to implement the Global Strategy in the security and defence domain. Also, this document further elaborates a new level of ambition aims to develop a stronger European Union in the area of security and defence. In line with this, the European Union should contribute to: (1) responding to external conflicts and crises, (2) building the capacities of partners, and (3) protecting the Union and its citizens. In this sense, Europe's strategic autonomy entails the ability to act and cooperate with international and regional partners wherever possible, while being able to operate autonomously when and where necessary (Council of the European Union, 2016c, paragraphs 5 and 18). Bilčik (2016) advocates the view that the Implementation Plan on Security and Defence should utilise the growing political consensus around EU security measures to push for concrete and credible defence initiatives.

In order to implement the level of ambition, several actions were proposed by the Implementation Plan on Security and Defence such as: to move forward with revision process of the Capability Development Plan; setting up the Coordinated Annual Review on Defence; address the gap at the strategic-level for the conduct of non-executive military CSDP missions; provide political guidance in view of a comprehensive review of the Athena mechanism; and provide full use of the Permanent Structured Cooperation (Council of the European Union, 2016c, paragraphs 26, 30, 32, 36, 37).

In line with Article 42 (6) of the Treaty on European Union, the Member States whose military capabilities fulfil higher criteria, and which have made more binding commitments to one another in this area with a view 
to the most demanding missions shall establish the Permanent Structured Cooperation (PESCO) within the Union framework. The Permanent Structured Cooperation was introduced by the Lisbon Treaty on the European Union in 2009 in order to provide defence cooperation in smaller committed groups and pursue the Common Foreign and Security Policy. Since then, the PESCO has been a 'sleeping beauty'.

According to the Council Conclusions on 14 November 2016, the Permanent Structured Cooperation would aim to gather as many Member States to join in stepping up their security and defence commitments as an inclusive effort to strengthen the CSDP (Council of the European Union, 2016b, paragraph 17). After that, in June 2017, the Council agreed on the need to launch an inclusive and ambitious Permanent Structured Cooperation with concrete collaborative projects and initiatives (Council of the European Union, 2017b, paragraph 8). Officially, the PESCO was triggered by the Council on 11 December 2017 while the first initial list of the seventeen projects was adopted on 6 March 2018 (Council of the European Union, 2017c; 2018a). Until now, there have been two more waves of extending the PESCO projects - seventeen additional projects approved on 19 November 2018 and an additional thirteen projects on 12 November 2019 (Council of the European Union, 2018b; 2019b). The next call for PESCO projects would take place in 2021 in order to ensure better coherence and synchronisation of the European Union's defence initiatives and focus on more substantiated projects.

Almost all scholars and practitioners agreed the PESCO was a prominent example of how the European Union's Member States started cooperating in unprecedented ways to strengthen their defence within concrete projects. The Permanent Structured Cooperation provides a binding framework in order to improve joint defence investment, cooperation and operational readiness among the participating Member States, individually responsible for fulfilling the commitments they have made to one another. It means that the PESCO 'breaks with the previously dominant voluntarism in European defence and introduces a legally binding character of defence cooperation' (France et al., 2017, p. 4.).

In May 2019 the Council assessed the contributions made by the participating Member States within the PESCO framework and encouraged them to advance the work and focus on the swift and effective implementation of the projects in which they participate in order to deliver tangible outputs and products, with a view to fulfilling the more binding commitments (Council of the European Union, 2019a). In this 
sense, Blockmans argues that for the successful PESCO implementation, the European Union should overcome at least three key challenges: (1) raising the level of ambition while ensuring inclusivity; (2) maintaining credibility in case participating States do not comply with their commitments; and (3) ensuring coherence with the many other building blocks in Europe's defence architecture (2018, pp. 1811-1824).

On the other side, to keep and further improve positive political momentum in European defence cooperation, some scholars, for example, Besch argues that the European Union should avoid the PESCO since reviving this mechanism would likely take too much time to agree on participation criteria (2016, p. 8). Also, most Member Countries still associate the PESCO with 'its toxic history as a stillborn instance of European defence cooperation' (2016, p. 8). Instead of the PESCO, Besch proposes that the European Union should consider deepening defence cooperation among the Member States within NATO's Framework Nations Concept (2016, pp. 31-32).

The Coordinated Annual Review on Defence (CARD) was created in 2017 to deepen cooperation in the defence domain (Council of the European Union, 2017d, paragraph 10). In the same document, the Council highlighted that the CARD would be implemented voluntarily, and the importance of bringing greater transparency and political visibility to the European capability landscape. Due to the fact that the CARD should serve as a link among the Member States' national defence planning and the European Union priorities, the Council recommended that the first full CARD must be implemented based notably on the revised Capability Development Plan priorities as well as other existing processes and tools as of 2018 (Council of the European Union, 2017d, paragraph 13). The Council in May 2017 endorsed the modalities to establish the CARD and launched the Trial Run (Council of the European Union, 2017e, paragraphs 19-22). In accordance with these modalities, the CARD pilot project was completed in 2018, and the first full CARD cycle based on the new European Defence Agency's Capability Development Plan was launched in autumn 2019.

Regarding the Global Strategy, the European Defence Agency 'has a key role to play by strengthening the Capability Development Plan, acting as an interface between the Member States and the Commission, and assisting the Member States to develop the capabilities stemming from the political goals set out in this Strategy' (European External Action Service, 2016, p. 46). The European Defence Agency's Steering Board endorsed the 
Capability Development Plan (CDP) on 28 June 2018 and approved development priorities. In line with the European Defence Agency's approach, the CDP should provide a full capability picture to support decision-making processes at the European Union's level and national levels regarding capability development. In addition, the CDP should prioritise military capabilities that need to be addressed and developed by the Member States and underpins the identification of cooperative activities that can be implemented by the Member States in the cooperation framework of their choice, including under the Permanent Structured Cooperation and the European Defence Fund. Also, the CDP is an outputoriented, and this is further reinforced by the Strategic Context Cases and corresponding implementation roadmaps, with a view to support the Member States in the implementation of the European Union's Capability Development Priorities (European Defence Agency, 2018). ${ }^{11}$

The Council approved in March 2017 the Concept Note on the operational planning and conduct capabilities for the CSDP missions and operations and established a Military Planning and Conduct Capability (MPCC) within the EU Military Staff in Brussels, which will be responsible for the operational planning and conduct of non-executive military missions at the strategic level, working under the political control and strategic guidance of the Political and Security Committee (Council of the European Union, 2017d, paragraph 5). As mentioned in The European Union's Global Strategy - Three Years on, Looking Forward, the MPCC is the first-ever unified command centre for the European Union's military training missions. It works closely with its civilian counterpart to ensure maximum coordination between military and civilian missions. Also, by the end of 2020, the MPCC should be ready to also run one executive military operation, of the size of an EU Battlegroup (European External Action Service, 2019, p. 34).

The High Representative in June 2018 proposed a European Peace Facility (EPF) to allow financing of all Common Foreign and Security

\footnotetext{
${ }^{11}$ Set of the EU Capability Development Priorities was proposed by the EDA and approved by the Member States as follows: (1) Enabling capabilities for cyber responsive operation; (2) Space-based information and communication services; (3) Information superiority; (4) Ground combat capabilities; (5) Enhanced logistic and medical supporting capabilities; (6) Naval manoeuvrability; (7) Underwater control contributing to resilience at sea; (8) Air superiority; (9) Air mobility; (10) Integration of military air capabilities in a changing aviation sector; and (11) Cross-domain capabilities contributing to achieve EU's level of ambition (European Defence Agency, 2018, p. 3).
} 
Policy external action with military and defence implications and to enhance the European Union's ability to safeguard European security interests and prevent conflict, build peace and strengthen the security around the world. In line with this proposal, the Foreign Affairs Committee drafted a recommendation concerning the European Peace Facility. This recommendation was adopted by the European Parliament in March 2019 in order to establish the EPF and yield synergies and efficiency gains by providing a package approach to the operational funding of external action that already exists today, and where funding from the European Union's budget is not possible (European Parliament, 2019).

The EPF is constituted as an off-budget fund, worth $€ 10.5$ billion for the period of seven years from 2021 to 2027, builds on and merges existing mechanisms (the African Peace Facility and the Athena mechanism) into a single fund with the following aims: (1) facilitating the European Union's military operations by providing a permanent fund with an enhanced scope of common costs compared to the Athena mechanism; (2) expanding the European Union's scope for financing peace support operations to third states and international organisations on a global scale; and (3) broadening the European Union support for the capabilitybuilding activities of armed forces in partner countries (Council of the European Union, 2018c). In accordance with the current intentions, the EPF would raise the share of operations' common costs to a maximum of $35-45 \%$, instead of $10-15 \%$ covered by the Athena mechanism.

\section{The European Defence Action Plan}

The European Union's Member States spend more than 210 billion Euros on defence and have about 1.5 million troops. ${ }^{12}$ Despite the fact that the European Union has the second-largest defence budget, this community is too far from being the second military power in the world. The main reason for this ineffectiveness is the fact that within the European Union exists a lot of duplication of capacities, including weapons, combat platforms, and systems. In this sense, the European

\footnotetext{
${ }^{12}$ In accordance with Besch, the United Kingdom accounts for about a quarter of EU Member States' defence spending and about a quarter deployable European troop (2016, p. 7). Apart from that, the UK's departure from the European Union means that some $80 \%$ of NATO's budgetary and military contributions will come from non-EU Member Countries (Bilčik, 2016, p. 12).
} 
Union should provide more value for its money. Thus, Mattelaer pointed out that the European dimension of defence planning begins with industrial aspects and setting appropriate financial incentives (2016, p. 37). The European Defence Agency in Defence Data calculated that in 2014, 77.9 percent of all equipment procurement took place at the national level (European Defence Agency, 2017). Owing to that, the Global Strategy identifies a number of priority areas for joint investment and development, which implies a more innovative and competitive industrial base and represents one of the main drivers to the European Defence Action Plan (European External Action Service, 2016, p. 45).

The Commission in November 2016 launched its European Defence Action Plan (EDAP) in order to support Europe's defence industry and the entire cycle of capability generation, from research and development to production and acquisition. The EDAP has three main pillars that address different but complementary needs along the capability development cycle, focusing on technologies and products: (1) launching a European Defence Fund; (2) fostering investments in defence supply chains; and (3) reinforcing the single market for defence (European Commission. 2016, p. 5). The EDAP should enhance cooperation among the Member States, including also promotion of greater pooling of national defence resources and strengthening the European internal market in the defence domain.

The European Defence Fund (EDF) consists of two distinct but complementary financing structures ('windows'): (1) A 'research window' to fund collaborative defence research projects at the European Union's level; and (2) A 'capability window' to support the joint development of defence capabilities commonly agreed by the Member States (European Commission, 2016, pp. 5-6). This is in accordance with Giegerich's proposal that financial incentives should focus on two points: first, kickstarting cooperation through seed funding and, second, maintaining capabilities through cooperation (2016, p. 28).

In the preparatory phase, two pilot programmes were established for the period from 2017 to 2020 with the aim to test the future European Defence Fund that will be implemented for the next Multi-annual Financial Framework from 2021 to 2027. First, the Preparatory Action on Defence Research was established with 90 million Euros to support collaborative research and technology projects from 2017 to 2019. Second, the European Defence Industrial Development Programme was established with 500 million Euros to co-finance joint industrial projects 
in the development phase from 2019 to 2020. For the next Multi-annual Financial Framework from 2021 to 2027, the European Defence Fund is worth 13 billion Euros, divided into 4.1 billion Euros for research and 8.9 billion Euros for development (European Commission, 2018).

The main purpose of the European Defence Fund is to incentivise cooperative projects among the Member States, such as joint defence research, capability development and procurement, and generate real financial incentives for systematic defence industrial cooperation in research and capability development, including also the collaborative projects launched in the PESCO framework. ${ }^{13}$

\section{EU-NATO Joint Declarations}

Some scholars and policy makers advocate an approach that the European Union should keep continuity in relying on NATO in order to build its own defence capacities. ${ }^{14}$ In any case, as stated in The EU and NATO - the Essential Partners, a momentum for renewed cooperation between NATO and the European Union has emerged in the last few years (Lindstrom and Tardy, 2019).

The European Union and NATO signed the Joint Declaration during the NATO Summit in Warsaw in July 2016 in order to provide new impetus and new substance to the strategic partnership through the seven areas of cooperation: Countering hybrid threats; Operational cooperation in the maritime domain; Cyber security and defence; Defence capabilities; Defence industry and research; Exercises; and Supporting partners' capacity building efforts (European Council, 2016b). In line with the Joint Declaration on cooperation from Warsaw in December 2016, the Council of the EU and the North Atlantic Council endorsed a common set of 42 actions for practical implementation in seven mentioned areas and introduced a monitoring mechanism (Council of the European Union,

${ }^{13}$ Normal projects get $20 \%$ financial support while the PESCO projects receive $30 \%$ from the European Defence Fund.

${ }^{14}$ Thus, Mölling proposed the interrelated steps: '(1) transfer NATO's Framework Nations Concept into the EU; (2) apply the Framework Nations Concept principles to the EU Battlegroups; (3) turn the EU Battlegroups into a European Combat Brigade (a sort of 'EU Very High Readiness Joint Task Force', or EU VJTF) by increasing their size and capabilities; (4) then earmark this EU VJTF for operations (in the east) in support of the EU assistance clause (Article 42(7) of the Treaty on European Union)' (2016, pp. 39-40). 
2016d). After that, in December 2017, a new common set of 32 proposals was adopted to consolidate progress and ensure further advances in all areas listed in the Joint Declaration (Council of the European Union, 2017a). As Blockmans observes, these 74 actions '....are an attempt to banish ghosts from the past in coordination between the two Brusselsbased organizations' (2018, p. 1792).

After that, in 2018, the second Joint Declaration was signed between the European Union and NATO with the aim to provide swift and demonstrable progress, in particular in: military mobility; counterterrorism; strengthening resilience to chemical, biological, radiological and nuclear-related risks; and promoting the women peace and security agenda (European Council, 2018, paragraph 6).

\section{THE REPUBLIC OF SERBIA AND THE EUROPEAN UNION - COOPERATION IN THE DEFENCE DOMAIN -}

\section{Drivers of Deepening Cooperation between the Republic of Serbia and the European Union}

Several main drivers of deepening cooperation between the Republic of Serbia and the European Union could be identified in line with the current circumstances. The most important are the following: Serbia is an EU candidate country, the Ministry of Defence and the Serbian Armed Forces are very active players within the framework of the CSDP, and Serbia is a militarily neutral country.

The Republic of Serbia belongs to the community of the EU candidate countries, with a significant contribution to the European Union's Common Security and Defence Policy. The partnership between the European Union and third countries within the CSDP has several different aims, such as participation in non-executive missions and operations, preventing or managing a crisis in the most proper way, capacity building, enhancing the resilience of a particular country or region, and improving dialogue.

Participation of the Republic of Serbia in the activities of the CSDP is of particular importance for the improvement of its national security and defence. The Serbian Armed Forces take participation in one EU operation NAVFOR-Atalanta and three non-executive missions EUTM Somalia, EUTM Mali and EUTM RCA, and in this way develop very close cooperation with the European Union. In addition, Serbia is developing 
capacities to enable it to participate in civilian missions under the Common Security and Defence Policy. Moreover, Serbia is a part of the European Union's Battlegroup - HELBROC, which consists of Greece, Bulgaria, Romania, Cyprus, and Ukraine.

In line with the Defence Strategy of the Republic of Serbia, military neutrality is a defence interest of the Republic of Serbia which is pursued by fulfilling the following goals: (1) not joining politico-military alliances; (2) integral engagement of defence system actors and defence capacities; and (3) creating conditions for defence based on its own strengths and capacities (Ministry of Defence of the Republic of Serbia, 2019, p. 15). Stojković and Glišić (2018) show that Serbia does not have a long tradition of military neutrality through a detailed analysis of previous Serbian military alliances with other countries, and explain the problem with defining Serbia's military neutrality due to the fact there is no official document which defines what this neutrality means in practice. Therefore, Serbia has close links with different military alliances and important partners, which has brought some peculiarities within the Serbian defence policy and the concept of military neutrality (Stojković and Glišić, 2018).

\section{The Global Strategy Implementation and Fostering Defence Cooperation with the Republic of Serbia}

The implementation process of the EU Global Strategy can trigger deeper cooperation with the Republic of Serbia in the defence domain through some actions within the Implementation Plan on Security and Defence, the European Defence Action Plan and the EU-NATO Joint Declarations. In the framework of the Implementation Plan on Security and Defence, we can say that all respective contents have a positive impact on deepening defence cooperation between the Republic of Serbia and the European Union.

In accordance with the Council conclusions from November 2017, third states may exceptionally be invited by project participants within the PESCO, in line with general arrangements to be decided in due time in accordance with Article 46 (6) of the Treaty on the European Union. In this case, third states would need to provide substantial added value to the PESCO project, contribute to strengthening the PESCO and the CSDP and meet more demanding commitments, while fully respecting the principle of decision-making autonomy of the EU and its Member States. Besides, this will not grant decision powers to such third states in the 
governance of the PESCO. Moreover, the Council in the PESCO format will decide if the conditions set out in the general arrangements are met by each third state invited by the respective project participants (Council of the European Union, 2017f, paragraph 2). In this context, the European Union looks forward to the adoption as soon as possible of a Council Decision on the general conditions under which third states could exceptionally be invited to participate in individual PESCO projects.

Despite the announcements given by the European Union and clear intentions of most Member States, the decision on third states' participation within the PESCO projects has not been made until now. The European Union's Member States are deeply divided regarding this matter. On the one side, there is a group of the Member States which speak in favour of a flexible approach, such as Benelux countries, Poland, Lithuania, Estonia, Sweden, Finland, the Czech Republic, Slovakia and Portugal. Likewise, France, Germany, Italy and Spain, as the most active countries within the PESCO, have a different approach giving more importance to the political dimension of the PESCO, including the existence of ambitions among third states regarding European defence cooperation and European integration.

The Republic of Serbia is interested in joining some PESCO projects, and for this reason, pays full attention to possible third states' involvement. Germany has already asked the question about possible Serbian engagement within the PESCO project - the European Medical Command. Taking into account that military medicine represents the most significant Serbian brand in the CSDP missions and operations without any doubts, Serbia is able to provide substantial added value to this concrete PESCO project, and also contribute to strengthening the PESCO and the CSDP. Apart from the mentioned project, Serbia should also take part in some other projects within the PESCO such as European Training Certification Centre for European Armies, Cyber Threats and Incident Response Information Sharing Platform, Helicopter Hot and High Training, and European Medium Altitude Long Endurance Remotely Piloted Aircraft Systems. These proposals are based on contemporary requirements arising from the reform process of the Serbian Armed Forces, ongoing acquisition projects, and from an already established level of cooperation with European countries.

The Coordinated Annual Review on Defence was created primarily to deepen defence cooperation among the Member States. In the framework of NATO's Partnership for Peace Programme, Serbia regularly 
participates in the Planning and Review Process with the aim to provide greater transparency and synergy in defence planning and capability development. The mentioned engagement could be very helpful for better understanding the CARD and possible participation in this mechanism in the foreseeable future.

The Capability Development Plan's mid-term perspective and longerterm perspective could provide a significant framework for defence planning and capability development in the Serbian Ministry of Defence. In addition, the CDP is an output-oriented and reinforced by the Strategic Context Cases and corresponding implementation roadmaps in order to support the European Union's Capability Development Priorities. In accordance with the European Defence Agency's approach, the Strategic Context Cases highlight in particular the major challenges to the coherence of the European capability landscape in each of the European Union's Capability Development Priorities in the short, medium and long term and provide connections between capabilities and development. The Republic of Serbia signed in December 2013 the Administrative Arrangement with the European Defence Agency and has already joined several concrete projects in line with the Capability Development Plan.

The Republic of Serbia participates in four of the six CSDP operations/missions and the EU Battlegroup HELBROC. Based on a significant contribution to the Common Security and Defence Policy, the European Union accepted the nomination of the Serbian officer for the liaison with the Military Staff in Brussels at the end of 2017. It was the first military officer in this position from a third country community. As the Serbian Ministry of Defence noted on its website, the nomination of the liaison officer represents a step further in strengthening the relations, deepening cooperation and establishing more efficient communication in the field of the EU CSDP, which is in accordance with the efforts made by the Republic of Serbia towards full membership in the European Union. Also, the Military Planning and Conduct Capability provides a new opportunity for secondment posts for Serbian military officers in the foreseeable future and further deepening defence cooperation between the Republic of Serbia and the European Union.

One of the aims of the European Peace Facility is related to expanding the European Union's scope for financing peace support operations to third states and international organisations on a global scale. This can be a trigger for further and more active Serbian contribution in the CSDP 
operations/missions and more prominent engagement in the concept of the EU Battlegroups.

As already mentioned, the main purpose of the European Defence Fund is to incentivise cooperative projects among the European Union's Member States, including also the collaborative projects launched in the PESCO framework. The Republic of Serbia as a third country with the possibility to participate in the PESCO projects could be a reliable partner to take some advantages established by the European Defence Action Plan.

Under the framework of the EU-NATO Joint Declarations, the Republic of Serbia has the opportunity to improve cooperation with these two organizations, primarily in two areas of cooperation - exercises and supporting partners' capacity building efforts. The Serbian Armed Forces conduct several exercises with the EU and NATO every year in order to improve interoperability and conduct pre-deployment training. In addition, NATO trained Iraqi medical officers in cooperation with Serbia in December 2017 within the framework of the Defence Capacity Building Initiative.

\section{CONCLUSION}

The Global Strategy announced that the European Union would 'systematically encourage defence cooperation and strive to create a solid European defence industry' (European External Action Service, 2016, p. 11). Furthermore, the broad European project in the defence domain is supported by over 70\% of the European Union's citizens (Centre for European Policy Studies, 2015, p. 2). In order to speed up the implementation process of the Global Strategy, the European Union recalls the need for fostering greater and more systematic European defence cooperation to deliver key capabilities, including through EU funds. Almost all scholars and policy makers agree with the statement that the Permanent Structured Cooperation and European Defence Fund are the most important game-changers in deepening defence cooperation within the European Union. Also, the coherent implementation of the PESCO, EDF and CARD is key to increasing the efficiency and output of defence cooperation.

As enshrined in the Defence Strategy of the Republic of Serbia, improvement of national security and defence through the process of European integration, while respecting the specificity of the Republic of Serbia, is the defence interest, which is achieved by fulfilling the following goals: (1) strengthening cooperative security with the European Union; 
(2) participation of the Republic of Serbia in the activities of the CSDP; (3) achieving the required level of capability for participation in the CSDP civilian missions; (4) enhanced scientific research and military-economic cooperation with the European Union (Ministry of Defence of the Republic of Serbia, 2019, p. 14). As noticed by Bakker et al., the CSDP is coming closer and closer to the EU's borders and this trend is making an arc of instability (2016, p. 1). In this contemporary environment, cooperation between the European Union and partners, including Serbia, is getting more and more important.

Based on analysis of over thirty official European Union's documents and twenty academic research papers we can conclude and confirm our general hypothesis that the EU Global Strategy implementation has a positive impact on defence cooperation with the Republic of Serbia, and also for engagement within the Common Security and Defence Policy, and provides concrete deliverables through several different ways thereby enhancing the integrative capacities for the EU membership. The above could be particularly visible within the Permanent Structured Cooperation and the European Peace Facility. In addition, Serbia should also improve cooperation with the European Defence Agency, taking into account that the role of the mentioned agency is getting more and more important for implementing the Permanent Structured Cooperation, the Coordinated Annual Review of Defence and the European Defence Fund.

Deepening defence cooperation between the Republic of Serbia and the European Union could have a positive impact on providing capacities needed for engagement within missions and operations within the Common Security and Defence Policy framework. This conclusion is primarily relevant regarding the Capability Development Plan and the European Peace Facility.

Finally, improving defence cooperation with the European Union paves the way to Serbian membership to the European community and especially supports negotiation process within the Chapter 31 - the Common Foreign, Security and Defence Policy related to the EU missions and operations.

Nevertheless, the Republic of Serbia should be aware that deepening defence cooperation with the European Union and some other partners cannot be a substitute for the robust national efforts. Due to the fact that the Global Strategy implementation process in practice requires synergy with NATO, the Republic of Serbia should also keep continuity with NATO cooperation under the Partnership for Peace Programme, 
especially using mechanisms such as the Planning and Review Process and the Operational Capabilities Concept.

\section{REFERENCES}

Andersson, J.J., Biscop, S., Giegerich, B., Mölling, C. \& Tardy, T. (2016). Envisioning European Defence - Five Futures. Paris, European Union Institute for Security Studies.

Bakker, A., Drent, M., Landman, L. \& Zandee, D. (2016). A Stronger CSDP:

Deepening Defence Cooperation. The Hague, Netherlands Institute of International Relations Clingendael.

Besch, S. (2016). Consulting the experts, in: J.J. Anderson, F. Daniel \& A. Missiroli (Eds.), After the EU Global Strategy: Consulting the Experts Security and Defence (pp. 7-9). Paris, European Union Institute for Security Studies.

Bilčik, V. (2016). Consulting the experts, in: J.J. Anderson, F. Daniel \& A. Missiroli (Eds.), After the EU Global Strategy: Consulting the Experts Security and Defence (pp. 11-13). Paris, European Union Institute for Security Studies.

Biscop, S. (2017). Analysing the EU Global Strategy on Foreign and Security Policy, in: J. Rehrl (Ed.), CSDP Handbook (pp. 28-34). Vienna, Directorate for Security policy of the Federal Ministry of Defence and Sports of the Republic of Austria.

Blockmans, S. (2018). The EU's Modular Approach to Defence Integration: an Inclusive, Ambitious, and Legally Binding PESCO?, Common Market Law Review, 55 (6), pp. 1785-1826.

Brattberg, E. \& Valašek, T. (2019). EU Defence Cooperation: Progress Amid Transatlantic Concerns. Washington, Carnegie Endowment for International Peace.

Centre for European Policy Studies. (2015). More Union in European Defence - Report of CEPS Task Force. Centre for European Policy Studies, Brussels.

Council of the European Union. (2016a, October 17). Outcome of the Council Meeting. 3492 ${ }^{\text {nd }}$ Council Meeting. Foreign Affairs. Council of the European Union, Luxembourg. 
Council of the European Union. (2016b, November 14). Council Conclusions on implementing the EU Global Strategy in the area of Security and Defence. Council of the European Union, Luxembourg.

Council of the European Union. (2016c, November 14). Implementation Plan on Security and Defence. Council of the European Union, Luxembourg.

Council of the European Union. (2016d, December 6). Council Conclusions on the Implementation of the Joint Declaration by the President of the European Council, the President of the European Commission and the Secretary General of the North Atlantic Treaty Organization. Council of the European Union, Luxembourg.

Council of the European Union. (2017a, December 5). Council conclusions on the Implementation of the Joint Declaration by the President of the European Council, the President of the European Commission and the Secretary General of the North Atlantic Treaty Organization. Council of the European Union, Luxembourg.

Council of the European Union. (2017b, June 22/23). Council Conclusions. Council of the European Union, Luxembourg.

Council of the European Union. (2017c, December 11). Council decision on Establishing Permanent Structured Cooperation and Determining the List of the Participating Member States. Council of the European Union, Luxembourg.

Council of the European Union. (2017d, March 6). Council conclusions on progress in implementing the EU Global Strategy in the area of Security and Defence. Council of the European Union, Luxembourg.

Council of the European Union. (2017e, May 18). Council conclusions on Security and Defence in the context of the EU Global Strategy. Council of the European Union, Luxembourg.

Council of the European Union. (2017f, November 13). Council conclusions on security and defence in the context of the EU Global Strategy. Council of the European Union, Luxembourg.

Council of the European Union. (2018a, March 6). Council Decision on Establishing the List of Projects to be developed under PESCO. Council of the European Union, Luxembourg.

Council of the European Union. (2018b, November 19). Council conclusions on Security and Defence in the context of the EU Global Strategy. Council of the European Union, Luxembourg. 
Council of the European Union. (2018c, June 13). Proposal of the High Representative of the Union for Foreign Affairs and Security Policy, with the support of the Commission, to the Council for a Council Decision establishing a European Peace Facility. Council of the European Union, Luxembourg.

Council of the European Union. (2019a, May 14). Council recommendation on assessing the progress made by the participating Member States to fulfil commitments undertaken in the framework of permanent structured cooperation. Council of the European Union, Luxembourg.

Council of the European Union. (2019b, November 12). Council conclusions on amending and updating Decision (CFSP) 2018/340 establishing the list of projects to be developed under PESCO. Council of the European Union, Luxembourg.

Dyson, T. \& Konstadinides, T. (2013). European Defence Cooperation - Law and IR Theory. Hampshire, Palgrave Macmillan.

European Commission. (2016, November 30). Communication from the Commission to the European Parliament, the European Council, the Council, the European Economic and Social Committee and the Committee of the Regions. Europe Defence Action Plan. European Commission, Brussels.

European Commission. (2017). Reflection Paper on the Future of the European Defence. European Commission, Brussels.

European Commission. (2018, June 13). Proposal for a Regulation of the European Parliament and of the Council Establishing the European Defence Fund. European Commission, Brussels.

European Council. (2003). European Security Strategy - A Secure Europe in a Better World. European Council, Brussels.

European Council. (2008, December 11/12). Presidency Conclusions CONCL 5. European Council, Brussels.

European Council. (2013, December 19/20). Conclusions EUCO 217/13. European Council, Brussels.

European Council. (2015, June 25/26). Conclusions EUCO 22/15. European Council, Brussels.

European Council. (2016a, June 28). Conclusions EUCO 26/16. European Council, Brussels.

European Council. (2016b). Joint Declaration by the President of the European Council, the President of the European Commission, and 
the Secretary General of the North Atlantic Treaty Organization. European Council, Brussels.

European Council. (2018). Joint Declaration on EU-NATO cooperation by the President of the European Council, the President of the European Commission, and the Secretary General of the North Atlantic Treaty Organization. European Council, Brussels.

European Defence Agency. (2017). Defence Data 2006-2016. European Defence Agency, Brussels.

European Defence Agency. (2018). Capability Development Plan. European Defence Agency, Brussels.

European External Action Service. (2016). Shared Vision, Common Action: A Stronger Europe - A Global Strategy for the European Union's Foreign and Security Policy. European External Action Service, Brussels.

European External Action Service. (2019). The European Union's Global Strategy - Three Years on, Looking Forward. European External Action Service, Brussels.

European Parliament. (2016a). A Global Strategy on foreign and security policy - Tracking European Commission priority initiatives in 2016. European Parliament, Brussels.

European Parliament. (2016b). European Parliament resolution of 22 November 2016 on the European Defence Union. European Parliament, Brussels.

European Parliament. (2019). Decision establishing a European Peace Facility. European Parliament, Brussels.

European Political Strategic Centre. (2015). In Defence of Europe Defence Integration as a Response to Europe's Strategic Moment. European Political Strategic Centre, Brussels.

France, O., Major, C. \& Sartory, P. (2017). How to Make PeSco a Success, retrieved from https://www.iris-france.org/wp-content/uploads/ 2017/09/Ares-21-Policy-Paper-Sept-2017.pdf. Accessed 24 January 2020.

Giegerich, B. (2016). Consulting the experts, in: J.J. Anderson, F. Daniel \& A. Missiroli (Eds.), After the EU Global Strategy: Consulting the Experts - Security and Defence (pp. 27-29). Paris, European Union Institute for Security Studies. 
Iklody, G. (2017). The European Union and CSDP - State of Affairs, in: J. Rehrl (Ed.), CSDP Handbook (pp. 42-45), Vienna, Directorate for Security policy of the Federal Ministry of Defence and Sports of the Republic of Austria.

Keohane, D. (2016). Consulting the experts, in: J.J. Anderson, F. Daniel \& A. Missiroli (Eds.), After the EU Global Strategy: Consulting the Experts - Security and Defence (pp. 31-33). Paris, European Union Institute for Security Studies.

Koenig, N. (2018). Security and Defence: A Glass Half Full, retrieved from https://www.iai.it/sites/default/files/eugs_watch_3.pdf. Accessed 22 January 2020.

Lindstrom, G. \& Tardy, T. (Eds.). (2019). The EU and NATO - The Essential Partners. Paris, European Union Institute for Security Studies.

Mattelaer, A. (2016). Consulting the experts, in: J.J. Anderson, F. Daniel \& A. Missiroli (Eds.), After the EU Global Strategy: Consulting the Experts - Security and Defence (pp. 35-37). Paris, European Union Institute for Security Studies.

Ministry of Defence of the Republic of Serbia. (2019). Стратегија одбране Републике Србије [Defence Strategy of Republic of Serbia], retrieved from http://www.mod.gov.rs/multimedia/file/staticki_sadrzaj/ dokumenta/strategije/2019/Strategija\%20odbrane\%20RS.pdf. Accessed 31 January 2019.

Missiroli, A. (Ed.). (2015). Towards an EU Global strategy - Background, process, references. Paris, European Union Institute for Strategic Studies.

Missiroli, A., Stang, G. et al. (2014). A Changing Global Environment. Paris, European Union Institute for Strategic Studies.

Mölling, C. (2016). Consulting the experts, in: J.J. Anderson, F. Daniel \& A. Missiroli (Eds.), After the EU Global Strategy: Consulting the Experts - Security and Defence (pp. 39-41). Paris, European Union Institute for Security Studies.

Pirozzi, N. \& Ntousas, V. (2019). Walking Strategic Talk - A Progressive EU Foreign Agenda for the Future. Rome, Instituto Affari Internazionali.

Stojković, D. \& Glišić, M. (2018). Serbia's Military Neutrality: Is It Economically Beneficial?. Defence and Peace Economics, pp. 1-17. Doi: https:// doi.org/10.1080/10242694.2018.1547952. 